\title{
Dynamics of dead wood decay in Swiss forests
}

\author{
Oleksandra Hararuk ${ }^{1,2^{*}}$ D, Werner A. Kurz ${ }^{2}$ and Markus Didion ${ }^{3}$
}

\begin{abstract}
Background: Forests are an important component of the global carbon (C) cycle and can be net sources or sinks of $\mathrm{CO}_{2}$, thus mitigating or exacerbating the effects of anthropogenic greenhouse gas emissions. While forest productivity is often inferred from national-scale yield tables or from satellite products, forest $\mathrm{C}$ emissions resulting from dead organic matter decay are usually simulated, therefore it is important to ensure the accuracy and reliability of a model used to simulate organic matter decay at an appropriate scale. National Forest Inventories (NFIs) provide a record of carbon pools in ecosystem components, and these measurements are essential for evaluating rates and controls of $\mathrm{C}$ dynamics in forest ecosystems. In this study we combine the observations from the Swiss NFIs and machine learning techniques to quantify the decay rates of the standing snags and downed logs and identify the main controls of dead wood decay.

Results: We found that wood decay rate was affected by tree species, temperature, and precipitation. Dead wood originating from Fagus sylvatica decayed the fastest, with the residence times ranging from 27 to 54 years at the warmest and coldest Swiss sites, respectively. Hardwoods at wetter sites tended to decompose faster compared to hardwoods at drier sites, with residence times 45-92 and 62-95 years for the wetter and drier sites, respectively. Dead wood originating from softwood species had the longest residence times ranging from 58 to 191 years at wetter sites and from 78 to 286 years at drier sites.

Conclusions: This study illustrates how long-term dead wood observations collected and remeasured during several NFI campaigns can be used to estimate dead wood decay parameters, as well as gain understanding about controls of dead wood dynamics. The wood decay parameters quantified in this study can be used in carbon budget models to simulate the decay dynamics of dead wood, however more measurements (e.g. of soil C dynamics at the same plots) are needed to estimate what fraction of dead wood is converted to $\mathrm{CO}_{2}$, and what fraction is incorporated into soil.
\end{abstract}

Keywords: Carbon residence time, Carbon dynamics, National Forest Inventory

\section{Background}

Under the United Nations Framework Convention on Climate Change (UNFCCC) and Kyoto Protocol, the countries that ratified the above are required to report their greenhouse gas (GHG) emissions and removals. Forests are an important component of such reports, because

\footnotetext{
* Correspondence: ohararuk@ucf.edu

'Department of Biology, University of Central Florida, 4110 Libra Dr, Orlando,

FL 32816, USA

${ }^{2}$ Pacific Forestry Centre, 506 Burnside Road West, Victoria, British Columbia

V8Z 1M5, Canada

Full list of author information is available at the end of the article
}

forests can be sources or sinks of $\mathrm{CO}_{2}$, depending on the net balance of $\mathrm{CO}_{2}$ emissions and removals. The rate of forests' carbon (C) removal is dependent primarily on their species composition, age of the living biomass, and climate (Churkina and Running 1998; Pregitzer and Euskirchen 2004; Drake et al. 2011). The rate of forests' $\mathrm{CO}_{2}$ emissions from decomposition is determined by the amount of dead organic matter stored in dead wood, litter, and soil in a forest stand, its degradability and climatic conditions (Prescott 2010; $\mathrm{Hu}$ et al. 2018). Forest productivity is often inferred from yield tables (e.g. Kurz et al. 2009) or from satellite

\section{SpringerOpen}

(c) The Author(s). 2020 Open Access This article is licensed under a Creative Commons Attribution 4.0 International License, which permits use, sharing, adaptation, distribution and reproduction in any medium or format, as long as you give appropriate credit to the original author(s) and the source, provide a link to the Creative Commons licence, and indicate if changes were made. The images or other third party material in this article are included in the article's Creative Commons licence, unless indicated otherwise in a credit line to the material. If material is not included in the article's Creative Commons licence and your intended use is not permitted by statutory regulation or exceeds the permitted use, you will need to obtain permission directly from the copyright holder. To view a copy of this licence, visit http://creativecommons.org/licenses/by/4.0/. 
products (e.g. Pan et al. 2006), whereas the dynamics of the dead organic matter are most commonly modeled (e.g. Kurz et al. 2009; Parton et al. 2010; Wang et al. 2010). These models usually consist of three parts: a first-order exponential decay of various components, such as dead wood; $\mathrm{C}$ transition rate from the upstream dead organic matter pools to the downstream pools, e.g. $\mathrm{C}$ transition from standing snags to downed logs; and $\mathrm{C}$ transfer efficiency from degradable to recalcitrant pools. To accurately determine the magnitude of forests' emissions of $\mathrm{CO}_{2}$ it is essential to use appropriate parameterization for the models of the dead organic matter dynamics.

Appropriate parameterization of models that simulate ecosystem $\mathrm{C}$ pools and fluxes can be achieved by using statistical techniques to inform model parameters with the observed C pools and fluxes (Williams et al. 2005; Luo et al. 2015). National Forest Inventories (NFIs) are an exceptional source of observations, because they provide records of living and dead biomass that can be converted to $C$ pools (Goodale et al. 2002; Tomppo et al. 2010) and used as a benchmark for model evaluation (Saatchi et al. 2011; Shaw et al. 2014) or a source of observations for calibration of model parameters (Hararuk et al. 2017). The long-term records made possible by regular NFI campaigns are particularly valuable for constraining $\mathrm{C}$ dynamics in slow-decomposing $\mathrm{C}$ pools, such as coarse woody debris, which often has high uncertainties around model predictions due to short-term or no observations (Williams et al. 2005; Keenan et al. 2012).

Decomposition of coarse woody debris depends mostly on microbial activity, which in turn is controlled by temperature and moisture conditions as well as wood traits and physical position of wood (i.e. whether dead wood is a standing snag or downed log). Increases in temperature promote microbial activity and increase the decomposition rate of coarse woody debris, which has been reflected in higher decay rate constants at warmer locations (Mackensen et al. 2003; Russell et al. 2014) and increases of withinsite respiration fluxes with warmer conditions (Herrmann and Bauhus 2013). Increased moisture also stimulates microbial activity on coarse woody debris, however, unlike the relationship with temperature, decay rate relationship with moisture content is parabolic due to oxygen limitation of microbial activity under high wood moisture content (Harmon et al. 1986; Olajuyigbe et al. 2012).

Downed logs have been shown to have higher decay rates compared to standing snags (Hararuk et al. 2017), which could be caused by faster colonization by microbes from direct contact with soil (Boddy 2001) or more favorable moisture conditions closer to soil surface (Shorohova and Kapitsa 2014; Př́ivětivý et al. 2018). Lastly, wood is highly variable in internal structure and chemical composition, which also has been shown to affect the speed of its decomposition. For instance, hardwoods have vessels that have larger diameters compared to the tracheids in softwoods, and are more continuous, which promotes faster colonization by fungi (Harmon et al. 1986; Wilcox 1973). Hardwoods also have higher nitrogen content and lower C:N ratios, which has been shown to stimulate wood decomposition rate (Weedon et al. 2009; Hu et al. 2018), whereas softwoods have higher lignin content (Savidge 2000; Weedon et al. 2009), which has been shown to protect wood from decay (Scheffer 1966; Freschet et al. 2012). Thus, both climatic and trait variables are important determinants of the wood decomposition rate ( $\mathrm{Hu}$ et al. 2018), and it is important to test and account for these controls during model development.

Apart from the microbe-driven decomposition of snags and logs, the bulk turnover rates of coarse woody debris are affected by the transition rates of snags into logs (or fall rates). Thus, quantifying only the decay rates of snags and logs would not give a full picture of dead wood fate, because fall rates might prolong or shorten dead wood residence times (cf. Angers et al. 2010). Unlike in the microbe-driven decay rates, there appears to be no clear pattern in factors that affect snag fall rates. For instance, while some studies reported that tree diameter at breast height (DBH) had a significant negative effect on snag fall rates (Mäkinen et al. 2006; Vanderwel et al. 2006b), others reported positive or no effect of DBH on snag longevity (Mäkinen et al. 2006; Angers et al. 2010). Similarly, a recent regional analysis of the U.S. forest inventory data revealed that snag fall rates tended to increase with mean annual temperatures (Oberle et al. 2018), however no temperature-dependent patterns in fall rates were evident from the regional analysis of data from permanent sample plots across Canada (Hilger et al. 2012), but the latter study reported that, on average, hardwood trees had lower fall rates compared to softwood trees. Given such variability in controls of snag fall rates and their substantial effect on bulk residence time of coarse woody debris, it is important to estimate snag fall rates and explore what affects their variability in Swiss forests.

In this study we quantify the snag fall rates, as well as the decay rates and residence times (the period, after which $90 \%$ of standing snags or downed logs would be decomposed) of standing and downed dead wood using data from the Swiss NFI. In Swiss forests dead wood comprises around $4.7 \%$ of growing stock $\left(\mathrm{m}^{3} \cdot \mathrm{ha}^{-1}\right)$ in hardwood-dominated stands, and $7.9 \%$ of growing stock in the softwood-dominated stands. These values decrease to $3.5 \%$ and $5.6 \%$, respectively when expressed as biomass (Brändli et al. 2020a, 2020b) as a result of a decrease in wood density during decomposition (Cioldi et al. 2020). Dead wood volume estimates alone, which are included in many NFIs, do not provide sufficient 
information on wood decay dynamics, because changes in dead wood densities (e.g. as in Paletto and Tosi 2010) are not reported, therefore the dynamics of the dead wood biomass needs to be simulated with a processbased $\mathrm{C}$ cycle model. To produce accurate estimates of dead wood biomass and $\mathrm{C}$ emissions it is essential to accurately represent the decay dynamics of dead wood in these process-based models, which can be achieved by using representative dead wood decay rates. Here, we use machine learning techniques to quantify the decay rates of standing snags and downed logs, and the dependency of these decay rates on climate and substrate recalcitrance.

\section{Methods}

\section{NFI data}

To estimate dead wood decay rates and factors determining their variability we used information from the Swiss National Forest Inventory (NFI). Data were available from four inventories (NFI1: 1983-1985, EAFV (Eidgenössische Anstalt für das forstliche Versuchswesen), BFL (Bundesamt für Forstwesen und Landschaftsschutz) 1988; NFI2: 1993-1995, Brassel and Brändli 1999; NFI3: 2004-2006, Brändli 2010; NFI4: 2009-2017, Brändli et al. 2020a, 2020b). The NFI is based on permanent sample plots located on a $1.4-\mathrm{km}$ grid covering the entire Swiss territory (Brändli and Hägeli 2019). Forested plots are identified based on aerial and terrestrial interpretation. Comprehensive stand and tree data are collected on all accessible plots excluding brush forests, e.g., in avalanche chutes (number of sampled plots during NFI1: 10,981; NFI2: 6412; NFI3: 6608; NFI4: 6042). Historically, the Swiss NFI has used a threshold of $12-\mathrm{cm}$ diameter at breast height (DBH) for identifying trees for repeated sampling (Lanz et al. 2019). All live and dead trees $>12 \mathrm{~cm} \mathrm{DBH}$ are measured on circular areas of $200 \mathrm{~m}^{2}$ and trees with DBH > $36 \mathrm{~cm}$ are measured on circular areas of $500 \mathrm{~m}^{2}$. Measured attributes of dead trees include $\mathrm{DBH}$, position with reference to the center of the sample plot, tree status (standing or downed), and decay status (five classes: raw wood, solid dead wood, rotten wood, mould wood, duff wood as defined in Hunter (1990)); decay status has only been recorded since NFI3. Based on the information from a previous inventory, including recorded tree position and mark of the DBH measurement along the stem, individual trees are located again in later inventories to ensure consistent measurements. Downed logs consistent of still compact pieces are only measured if they can be identified to be part of a previously alive sampled tree. The DBH of downed logs is measured twice, parallel and perpendicular to the ground to account for flattening during decomposition, and the mean of the two measurements is used for volume estimation.
The volume of live and dead trees is estimated as a function of DBH which was calibrated based on DBH, diameter at 7-m height, and total tree height from ca. Forty thousand tree $\mathrm{DBH}$ and height measurements (Lanz et al. 2019).

Volume estimates for snags and logs are converted to biomass by multiplying the former by measured wood densities obtained in a study by Dobbertin and Jüngling (2009) (see also Didion et al. 2019) for all five decay classes. In order to obtain accurate and representative data, the study by Dobbertin and Jüngling was restricted to snags and logs of Picea abies and Fagus sylvatica, the dominant coniferous and broadleaved tree species in Swiss forests (Table 1). Extrapolation of $F$. sylvatica wood densities to other hardwood species may be reasonable, because chemical composition of beech wood is similar to that of other hardwood species (Pettersen 1984; Popescu et al. 2011), whereas softwood species can vary substantially in wood chemical composition (e.g. lignin content (Pettersen 1984)), and thus wood densities across decay classes may not be similar among softwoods. However, most of snags and logs belonged to $P$. abies, therefore we do not expect the bias to be substantial. $\mathrm{C}$ content did not vary significantly across five decay classes and mean C concentrations of $49.3 \%$ for conifers and $47.6 \%$ for broadleaves were used to convert biomass

Table 1 Number of standing snags and downed logs by tree species over time

\begin{tabular}{lllll}
\hline & Species & NFI2 & NFI3 & NFI4 \\
\hline Standing & Picea spp. & 346 & 292 & 231 \\
& Abies spp. & 65 & 60 & 43 \\
& Pinus spp. & 40 & 31 & 21 \\
& Larix spp. & 41 & 37 & 36 \\
& Pinus cembra & 9 & 6 & 5 \\
& Fagus sylvatica & 53 & 37 & 28 \\
& Acer spp. & 2 & 2 & 2 \\
& Fraxinus spp. & 4 & 3 & 2 \\
Quercus spp. & 14 & 10 & 9 \\
& Castanea sativa & 79 & 71 & 66 \\
& Picea spp. & 210 & 264 & 325 \\
Abies spp. & 19 & 24 & 41 \\
& Pinus spp. & 37 & 46 & 56 \\
Larix spp. & 52 & 56 & 57 \\
& Pinus cembra & 4 & 7 & 8 \\
Fagus sylvatica & 29 & 45 & 54 \\
& Acer spp. & 2 & 2 & 2 \\
Fraxinus spp. & 3 & 4 & 5 \\
& Quercus spp. & 1 & 5 & 6 \\
Castanea sativa & 6 & 14 & 19 \\
\hline
\end{tabular}


into $C$ stocks regardless of the decay status (Didion et al. 2019). Since decay status has been recorded only since the NFI3, we followed the approach by Didion et al. (2014) to obtain estimates of biomass and carbon in dead trees at the time of the NFI2. To derive such estimates, first, trees were selected that were observed as dead in the NFI2 and were either alive in the NFI1 or not recorded in the NFI1 due to a diameter below the caliper threshold of $12 \mathrm{~cm}(n=269)$. Second, for the time of the NFI2 we quantified a range of $\mathrm{C}$ stock estimates for these trees based on decay class specific wood densities (Supplementary Table S1) and the measured C contents of $49.3 \%$ for conifers and $47.6 \%$ for broadleaves (cf. Didion et al. 2014). A high $C$ stock estimate was calculated based on wood density for decay class 1 ("raw wood"), and a low estimate was calculated using wood density for decay class 2 ("solid dead wood"). All other trees, i.e. trees that were recorded as dead during NFI1, NFI2, NFI3, and NFI4 $(n=747)$, decay class in NFI2 was assigned to be the same as observed in NFI3, yielding a low $\mathrm{C}$ stock estimate, or one less than recorded during NFI3, yielding a high C stock estimate. More details on C stock calculation are described in Didion et al. (2014). During parameter estimation in the wood decay model (see Eq. 1), we used the average of low and high $C$ stock estimates in NFI2 as the initial wood C pool values.

In total, data were available for 1016 individual dead stems across 671 plots that were measured repeatedly during NFI2, NFI3, and NFI4 (see Table 1 for number of standing snags and downed logs by tree species). Available measurements were as follows:

- DBH range: 12 to $109 \mathrm{~cm}$; mean: $29 \mathrm{~cm}$; median $24 \mathrm{~cm}$

- Volume range: 0.03 to $7.31 \mathrm{~m}^{3}$; mean: $0.84 \mathrm{~m}^{3}$; median $0.35 \mathrm{~m}^{3}$

- Biomass range: 12 to $2851 \mathrm{~kg}$; mean: $324 \mathrm{~kg}$; median $148 \mathrm{~kg}$

- Elevation range of sample plots: 322 to $2195 \mathrm{~m}$ a.s.l.

In addition to the collected NFI data, we extracted the observed climatic variables from a spatially gridded dataset prepared by the Federal Office of Meteorology and Climatology MeteoSwiss. Based on its station network across Switzerland and accounting for topographic effects, MeteoSwiss calculates near-surface climate variables on a high-resolution grid over Switzerland (MeteoSwiss, Federal Office of Meteorology and Climatology 2019). For the location of each NFI sampling plot, data for mean monthly absolute temperature $\left({ }^{\circ} \mathrm{C}\right)$ and for monthly precipitation sum $(\mathrm{mm})$ were extracted from the respective current versions of the gridded data, i.e. TabsM (MeteoSwiss, Federal Office of Meteorology and Climatology 2016a) and RhiresM v1.0 (MeteoSwiss, Federal Office of Meteorology and Climatology 2016b). Across the 671 NFI plots, mean annual temperatures (norm 1981-2010) ranged from $-2{ }^{\circ} \mathrm{C}$ to $12{ }^{\circ} \mathrm{C}$ with a mean and standard error of $5.5 \pm 0.1{ }^{\circ} \mathrm{C}$, and mean annual precipitation sum (norm 1981-2010) ranged from 540 to $2300 \mathrm{~mm}$ with a mean and standard error of $1453 \pm 14 \mathrm{~mm}$.

To examine potential drivers of decomposition that have been found in relevant studies, additional measured attributes were obtained from the NFI database; these attributes were available for NFI3 and NFI4 only:

- stem damage (Storaunet and Rolstad 2002); of the 1016 snags and logs used in this study, $41 \%$ in the NFI3 and 35\% in the NFI4 had no observed damage, $>80 \%$ had no or minor observed damage (Table 2)

- soil contact (Př́větivý et al. 2018);

- bark cover (Kahl et al. 2012).

\section{Model}

To quantify dead wood decay dynamics, we adopted a widely-used first order exponential decay approach (e.g. Scheller and Mladenoff 2004; Kurz et al. 2009; Hérault et al. 2010):

$$
X_{t}=X_{0} e^{-k_{10} \times f(T) \times t}
$$

where $X_{t}$ is $\mathrm{C}$ stock at the time $t ; X_{0}$ is the initial C stock; $k_{10}$ is the baseline decay rate, or decay rate at $T=$

Table 2 Observed damage on snags and logs used in this study

\begin{tabular}{|c|c|c|c|c|}
\hline \multirow[t]{2}{*}{ Observed damage } & \multicolumn{2}{|c|}{ Number of trees (NFI3) } & \multicolumn{2}{|c|}{ Number of trees (NFI4) } \\
\hline & Conifers & Broadleaves & Conifers & Broadleaves \\
\hline Snag - no damage & 204 & 80 & 139 & 71 \\
\hline Snag - single cut or break & 218 & 43 & 197 & 36 \\
\hline Snag - more than one cut or break & 4 & 0 & 0 & 0 \\
\hline Log - no damage & 112 & 21 & 110 & 34 \\
\hline Log - single cut or break & 170 & 35 & 219 & 33 \\
\hline Log - more than one cut or break & 115 & 14 & 158 & 19 \\
\hline Total & 823 & 193 & 823 & 193 \\
\hline
\end{tabular}


$10^{\circ} \mathrm{C}$; and $f(T)$ is temperature dependence of the dead wood decay rate, which is often represented as

$$
f(T)=Q_{10}^{\frac{T-10}{10}}
$$

where $Q_{10}$ is temperature sensitivity of decay, or a factor by which decay rate changes with a $10^{\circ} \mathrm{C}$ increase in temperature $(T)$.

\section{Parameter estimation}

We calibrated the model parameters using a Bayesian Markov Chain Monte Carlo (MCMC) technique (Besag et al. 1995). Bayesian inversion can be summarized as

$$
p(c \mid Z)=a \times p(Z \mid c) \times p(c)
$$

where $p(c \mid Z)$ is a posterior probability density function of parameters $c ; p(Z \mid c)$ is a likelihood function of parameters $c ; p(c)$ is a prior probability density function of parameters $c$; and $a$ is a normalization constant (Mosegaard and Sambridge 2002). Assuming that the prediction errors are uncorrelated and have a Gaussian distribution, the likelihood $p(Z \mid c)$ can be expressed as

$$
p(Z \mid c)=\exp \left\{-\sum_{i=1}^{2} \sum_{j=1}^{N_{i}} \frac{\left(x_{i}^{j}-z_{i}^{j}\right)^{2}}{2 \sigma_{i, j}^{2}}\right\}
$$

where $x_{i}^{j}$ is the modelled value for pool at time $i$ at a plot $j ; z_{i}^{j}$ is the observed value for pool at time $i$ at a plot $j$; $\sigma_{i, j}^{2}$ is the error variance for pool at time $i$ at a plot $j$; and $N_{i}$ is the number of observations collected during the NFI at time $i$. Our priors $p(c)$ were non-informative, therefore we used the form of the likelihood function derived by Box and Tiao (1992):

$$
p(Z \mid c) \propto \prod_{i=1}^{2}\left[\sum_{j=1}^{N_{i}}\left(x_{i}^{j}-z_{i}^{j}\right)^{2}\right]^{-0.5 N_{i}}
$$

The prior distributions for the parameters were assumed to be uniform. We sampled from the posterior parameter distribution $p(c \mid Z)$ by proposing a set of parameters and accepting or rejecting it using the Metropolis criterion (Spall 2005). Because the prior parameter distribution was uniform, we proposed new parameter sets using a uniform proposal distribution:

$$
c^{\text {new }}=c^{k-1}+r \times \frac{c^{\max }-c^{\min }}{D}
$$

where $c^{k-1}$ is the set of parameters accepted at simulation step $k-1 ; c^{\max }$ and $c^{\min }$ are upper and lower parameter limits; $r$ is a random number in the range $[-0.5$, $0.5]$; and $D=5$. Afterwards we calculated the probability of parameter acceptance:

$$
P\left(c^{\text {new }} \mid c^{k-1}\right)=\min \left\{1, \frac{P\left(Z \mid c^{n e w}\right)}{P\left(Z \mid c^{k-1}\right)}\right\}
$$

and compared the value of $P\left(c^{\text {new }} \mid c^{k-1}\right)$ with a random number $U$ drawn from a uniform distribution within a range $[0,1]$. If $U \leq P\left(c^{\text {new }} \mid c^{k-1}\right), c^{k}$ was set to $c^{\text {new }}$, otherwise $c^{k}$ was set to $c^{k-1}$. We repeated this procedure 300 times to generate a covariance matrix $C_{0}$, and then switched the parameter proposal distribution to the multivariate normal as in $\mathrm{Xu}$ et al. (2006) for the next 49,700 simulations:

$$
c^{\text {new }}=N\left(c^{k-1}, C_{k}\right)
$$

where $C_{k}$ is defined as in Haario et al. (2001):

$$
C_{k}= \begin{cases}C_{0} & k=300 \\ s_{d} \operatorname{cov}\left(c^{0}, \ldots, c^{k-1}\right) & k>300\end{cases}
$$

where $s_{d}=2.38 / \sqrt{n}$, and $n$ is the number of parameters in a model (Gelman et al. 1996). The rates of parameter acceptance were $15 \%-30 \%$, indicating good mixing, which is necessary to arrive at stable posterior distributions (Gelman et al. 1996). We discarded the first half of the accepted parameters as a "burn-in" period, and sampled 1000 estimates from the second half of the accepted parameters to generate the marginal posterior parameter distributions and calculate the maximum likelihood parameter values. We estimated the decay parameters for standing snags and downed logs separately, because, as reported previously, the downed logs decay faster than the standing snags (Krankina and Harmon 1995; Kurz et al. 2009; Hararuk et al. 2017).

\section{Analysis}

Studies that focus on wood turnover do not always calculate turnover rates, reporting wood half-lives or residence times instead of the turnover rate $k_{10} \times f(T)$ as presented in Eq. 1. Therefore, when comparing our calibrated turnover rates with the values reported in the literature we compare three estimates where applicable: turnover rates, residence times, or half-lives adjusted for local climatic conditions at the study site:

$$
k=k_{10} \times Q_{10}^{\frac{T-10}{10}}
$$

where $k$ is the turnover rate of the standing snag or downed log pool; $k_{10}$ is the baseline decay rate, or decay rate at $T=10^{\circ} \mathrm{C}$; and $Q_{10}$ is temperature sensitivity of decay. The residence time was assumed to be the period, after which $90 \%$ of standing snags or downed logs would be decomposed. For snags it was calculated as follows

$$
t_{0.9}=\frac{\ln (0.1)}{-(k+f)}
$$


where $f$ is the median fall rate estimated from Swiss NFI data. For logs the residence time was calculated as

$$
t_{0.9}=\frac{\ln (0.1)}{-k}
$$

Similarly, the half-lives were calculated as follows:

$$
t_{0.5}=\frac{\ln (0.5)}{-k}
$$

When the study that reported turnover rates, residence times, or half-lives did not report climatic data, we calculated turnover rates and residence times (Eqs. 10-12) using the long-term climatic averages from WorldClim (Fick and Hijmans 2017) for the corresponding geographic locations.

As mentioned previously, decay rates of snags and logs alone do not give a full picture of dead wood fate without incorporating the fall rates, which may prolong or shorten dead wood residence times. Unfortunately, there were many snag samples at Swiss NFI plots that did not transition into logs during more than 30 years of observations, so we made rough assumptions about snag fall rates in order to evaluate the ranges of total dead wood residence times. Fall rates were calculated from the data as the inverse of halved difference between the first date that a snag was classified a $\log$, and the first date the snag was classified as a snag; for all snags that remained standing for over 30 years, we assumed that they would fall within the next 5-7 years. This assumption appears justified given the findings by Mäkinen et al. (2006) who reported low probabilities of snags remaining upright for more than 40 years in Finnish forests, and findings by Storaunet and Rolstad (2004) who reported that $75 \%$ of snags would fall after 40 years.

\section{Identifying factors that affect wood decay}

We explored the dependence of the dead wood decay dynamics on different dead wood attributes including substrate recalcitrance, soil surface contact, bark cover, and damage, as well as climatic variables, such as temperature and precipitation. To explore this dependence, we tested whether the listed variables were significant predictors of the residuals of a model (Eq. 1), in which the base decay rate $k_{10}$ and temperature sensitivity $Q_{10}$ were calibrated against the decay dynamics over time of individual standing snags or downed logs. Softwood stems contain on average $10 \%$ more lignin than hardwood stems (Savidge 2000), which protects a plant cell from decay and has been associated with longer $\mathrm{C}$ residence times in wood (Freschet et al. 2012), therefore we assumed that binary classification of wood into hardwood (HW) and softwood (SW) type would be sufficient to detect the effect of substrate recalcitrance on dead wood decay. We used a machine learning technique, recursive partitioning by conditional inference (Hothorn et al. 2006), to represent model residuals as a function of substrate recalcitrance, soil surface contact, bark cover, degree of damage, climatic variables, such as temperature and precipitation, wood type (HW vs SW), and species to account for the possible species-specific factors not accounted by other variables in the model. Unlike many recursive partitioning methods, conditional inference trees do not overfit the models and are not biased towards covariates with many possible splits. This method is available in the R package "partykit" (Hothorn et al. 2015), which we used to analyze the residuals in this study.

We also used a conditional inference tree to explore whether wood type, diameter at breast height, temperature and precipitation were significant predictors of the calculated snag fall rates. Lastly, an exponential distribution was fitted to the frequency distribution of the fall rates using "fitdistrplus" package in R (Delignette-Muller and Dutang 2015), which yielded an optimal $\lambda=14$ (Supp. Figure S1). The fall rates were randomly drawn from the exponential distribution to simulate transition from standing to downed dead wood; and decay of snags and logs was simulated using Eq. 1.

\section{Results}

The best-fitting parameters indicated that in Swiss forests logs decay 1.7 times faster compared to standing snags (Fig. 1a, d); the baseline snag decay was $0.023 \mathrm{yr}^{-1}$, and $\log$ decay rate at $10^{\circ} \mathrm{C}$ was $0.04 \mathrm{yr}^{-1}$. Unlike baseline decay rates, temperature sensitivities $\left(Q_{10}\right)$ did not differ between the standing snags and downed logs (Fig. 1b, e). Overall, the $C$ half-lives in the snag pool varied from 22 years in the warmest NFI plots to 118 years in the coldest NFI plots, and in the log pool - from 11 to around 65 years (Fig. 1c, f).

Species, annual precipitation, and wood type were significant predictors of model residuals (Fig. 2), therefore, these variables influenced dead wood decay dynamics. The calibrated model overpredicted the mass of Fagus spp. snags by $63.2 \mathrm{~kg} \mathrm{C} \cdot \mathrm{ha}^{-1}$ in $50 \%$ of the cases (Fig. 2a), indicating that Fagus spp. snags decayed substantially faster compared to other snags. For snags that originated from other species, precipitation was a significant predictor of decay: at sites with annual precipitation less than $1837 \mathrm{~mm}$, snag mass was underpredicted by $5.6 \mathrm{~kg} \mathrm{C}$. $\mathrm{ha}^{-1}$ in $50 \%$ of the cases, indicating slower than expected decay rate at those sites, and at sites where annual precipitation exceeded $1837 \mathrm{~mm}$, the model overpredicted the snag mass by $8.2 \mathrm{~kg} \mathrm{C} \cdot \mathrm{ha}^{-1}$ in $50 \%$ of the cases, indicating the decay rate was faster than expected. Wood type was the only significant predictor of the model residuals for log mass. The calibrated model overpredicted hardwood $\log$ mass by $23.5 \mathrm{~kg} \mathrm{C} \cdot \mathrm{ha}^{-1}$ in $50 \%$ of the cases, indicating 


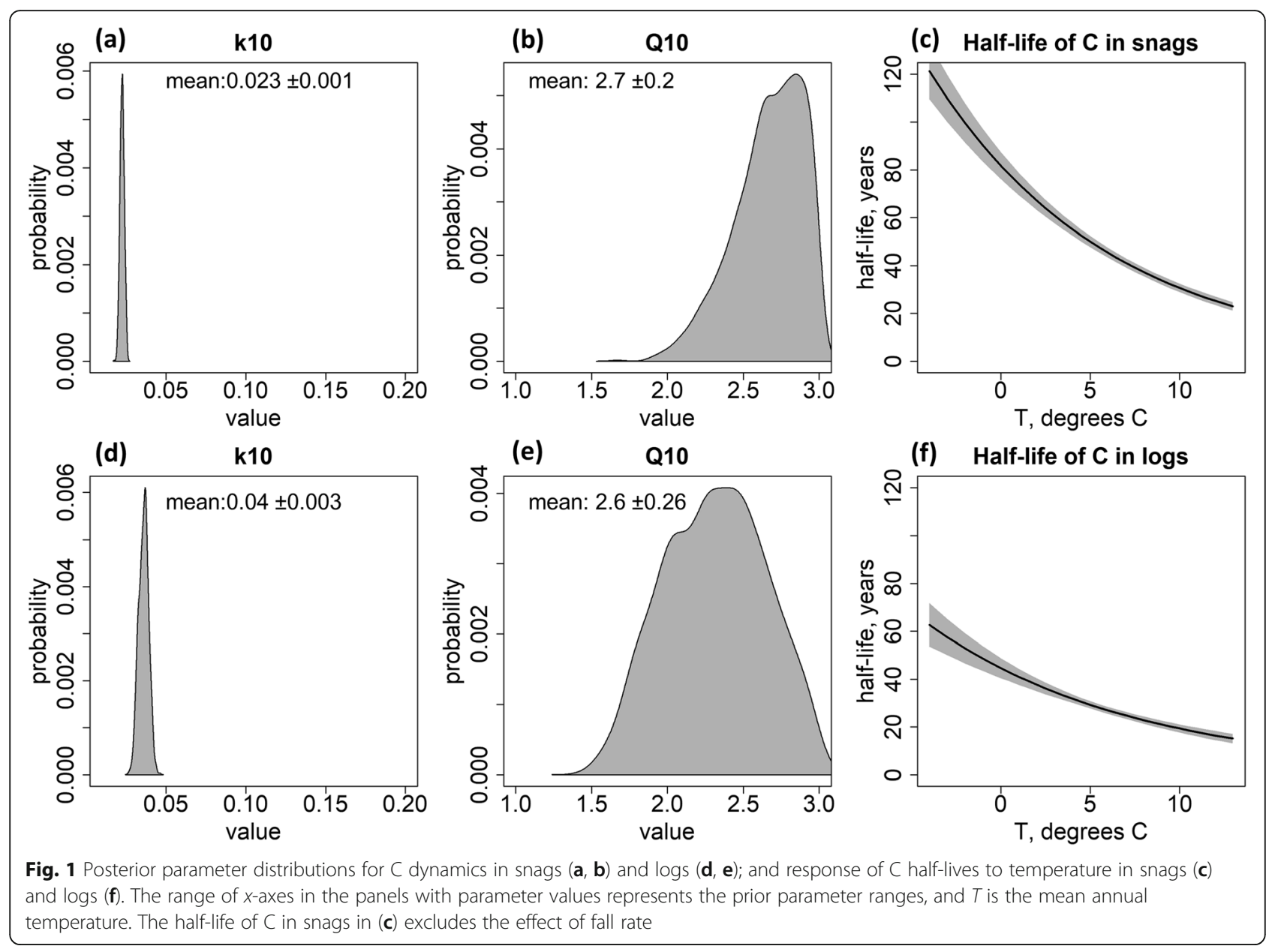

faster than expected decay rate for hardwood logs, and underpredicted softwood $\log$ mass by $6.1 \mathrm{~kg} \mathrm{C} \cdot \mathrm{ha}^{-1}$ in $50 \%$ of the cases, indicated slower decay of these logs than predicted by the calibrated model.

Significant effects of wood type, species, and precipitation on dead wood decay rates prompted us to estimate baseline decay rates and temperature sensitivities separately for $F$. sylvatica snags, non-Fagus spp. snags under high and low precipitation (i.e. PPT $>1837 \mathrm{~mm}$ and $\leq$ $1837 \mathrm{~mm}$, respectively), hardwood logs, and softwood logs to further characterize their decay dynamics. F. sylvatica snag baseline decay rate was $0.084 \mathrm{yr}^{-1}$ (Fig. 3a) and was 6-fold faster than base decay rate of snags in low precipitation plots (Fig. 3d), and 3-fold faster than the decay rate in high precipitation plots (Fig. 3g). Temperature sensitivity of $F$. sylvatica snag decay was highly uncertain (Fig. 3b), whereas temperature sensitivities of non-Fagus spp. snags were more constrained (Fig. 3e, h), with lower temperature sensitivity in dryer plots and higher in wetter plots. Overall, the $\mathrm{C}$ half-lives in F. sylvatica snags varied from 10 years in the warmest NFI plots to 25 years in the coldest NFI plots (Fig. 3c); and half-lives of non-Fagus spp. snags varied from 45 to
105 years in lower precipitation plots (Fig. 3f) and from 25 to 105 years in higher precipitation plots (Fig. 3i).

Downed logs of softwood species decayed at the rate of $0.036 \mathrm{yr}^{-1}$ under $10{ }^{\circ} \mathrm{C}$ temperature (Fig. 4a), whereas hardwood logs decayed faster, at the rate of $0.069 \mathrm{yr}^{-1}$ (Fig. 4d). However, the decay rate of softwood logs was more sensitive to temperature $\left(Q_{10}=2.3\right.$, Fig. $\left.4 \mathrm{~b}\right)$, compared to the decay rate of hardwood logs $\left(Q_{10}=1.36\right.$, Fig. 4e). The lower temperature sensitivities translated into lower variability of half-lives of hardwood logs across NFI plots, which ranged from 10 to 18 years (Fig. 4f), compared to the variability of half-lives of softwood logs (18-65 years, Fig. 4c).

Fall rates ranged from 0.02276 to $0.22 \mathrm{yr}^{-1}$, with $50 \%$ of the values being less than $0.04 \mathrm{yr}^{-1}$ (Supp. Figure S1). Fall rates were not significantly related to temperature, precipitation, or snag diameter, and therefore were randomly drawn from the exponential distribution (Supp. Figure S1) to simulate transition from standing to downed dead wood in order to estimate bulk wood decay rates in Swiss forests (Fig. 5).

The shortest dead wood residence times were for the wood originating from $F$. sylvatica, with $90 \%$ of mass gone after 27 years at the warmest sites, 35 years at the 


\section{(a) Snags}

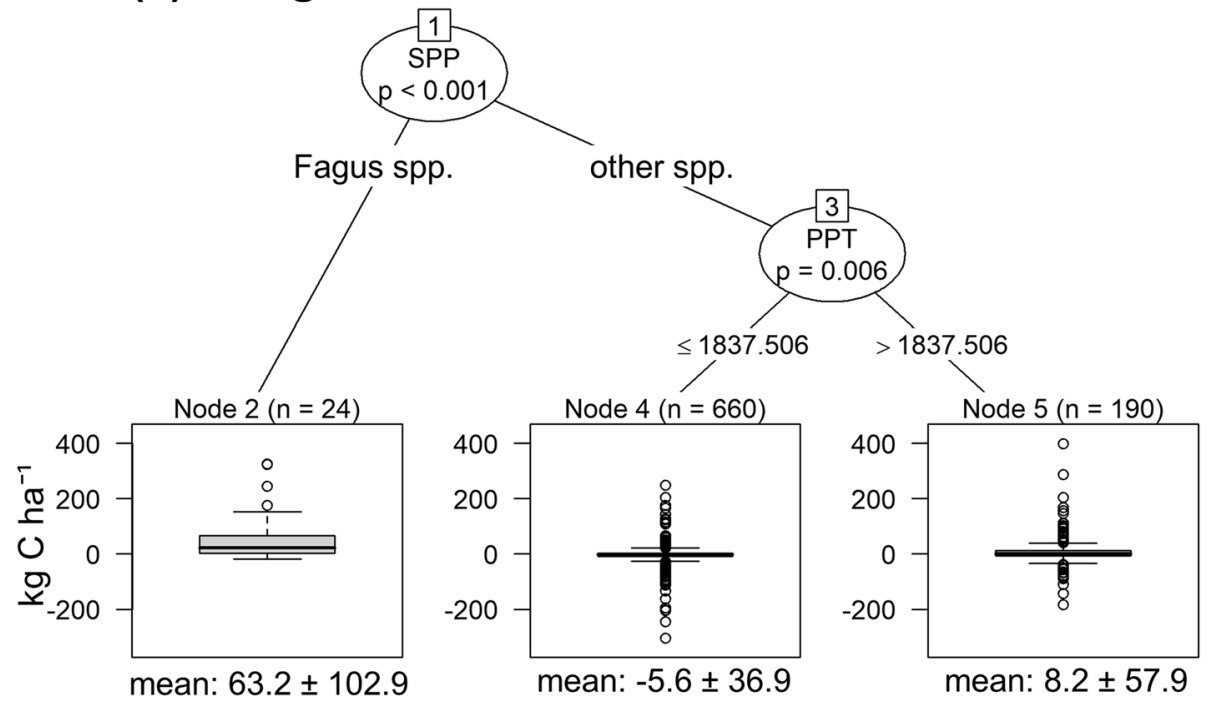

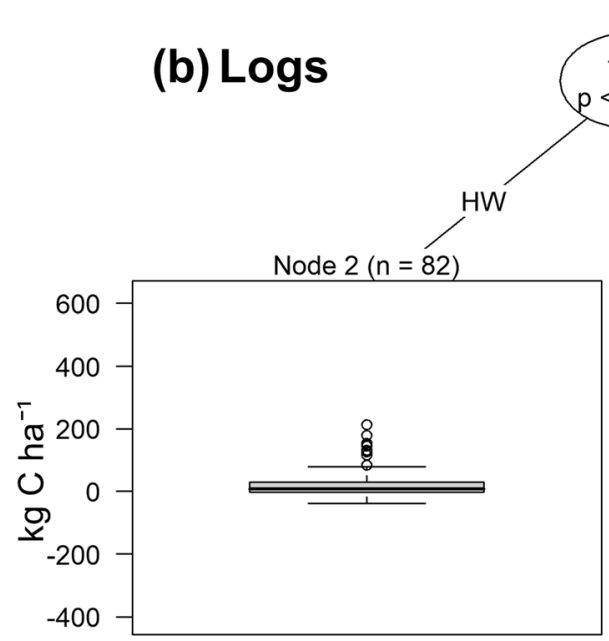

mean: $23.5 \pm 48.5$

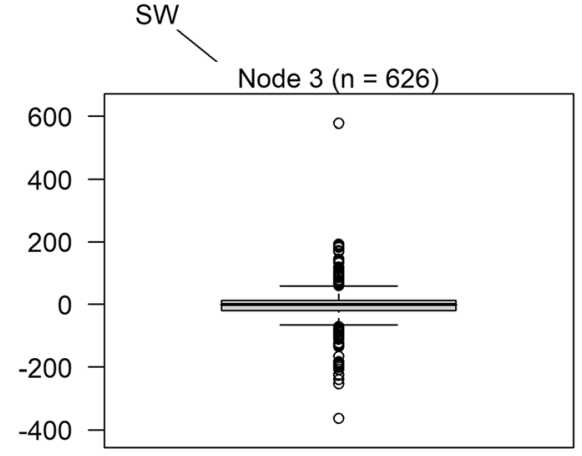

mean: $-6.1 \pm 60.2$

Fig. 2 Results of conditional inference tree, where the dependent variables were model residuals (modeled minus observed carbon stocks) and independent variable was wood type, hardwood (HW) or softwood (SW), and environmental variables. Wood type was a significant predictor of model residuals for downed logs, whereas species and annual precipitation were significant predictors for standing snags. Snags of Fagus spp. decayed significantly faster compared to other species, and non-Fagus spp. snags decayed faster in plots with higher precipitation. Logs of hardwood species decayed faster than logs of softwood species

average sites, and 54 years at the coldest sites (Fig. 5e). Other hardwood species growing in wet sites lost $90 \%$ of their mass after 45, 60, and 92 years at warmest, average, and coldest sites, respectively (Fig. $5 \mathrm{~d}$ ), and hardwoods growing at drier sites lost the $90 \%$ of mass after 62,73 , and 95 years for the same sites (Fig. 5c). Softwoods had the longest residence times, losing $90 \%$ of their mass after 58, 91, and 191 years at wetter warm, average, and cold sites (Fig. 5b), and 78, 135, and 286 years for the drier warm, average, and cold sites (Fig. 5a).

\section{Discussion}

\section{Snag and $\log C$ residence times}

This study is among the few that estimated decomposition rates of snags alone, without merging the decay rates with the fall rates, or combining the snag data with the downed dead wood that has contact with soil (e.g. Aakala 2010; Vacek et al. 2015). Furthermore, quantitative data on long-term dead wood decay from forests in the European Alps are rare (Petrillo et al. 2016). We assumed that the effects of substrate quality and 

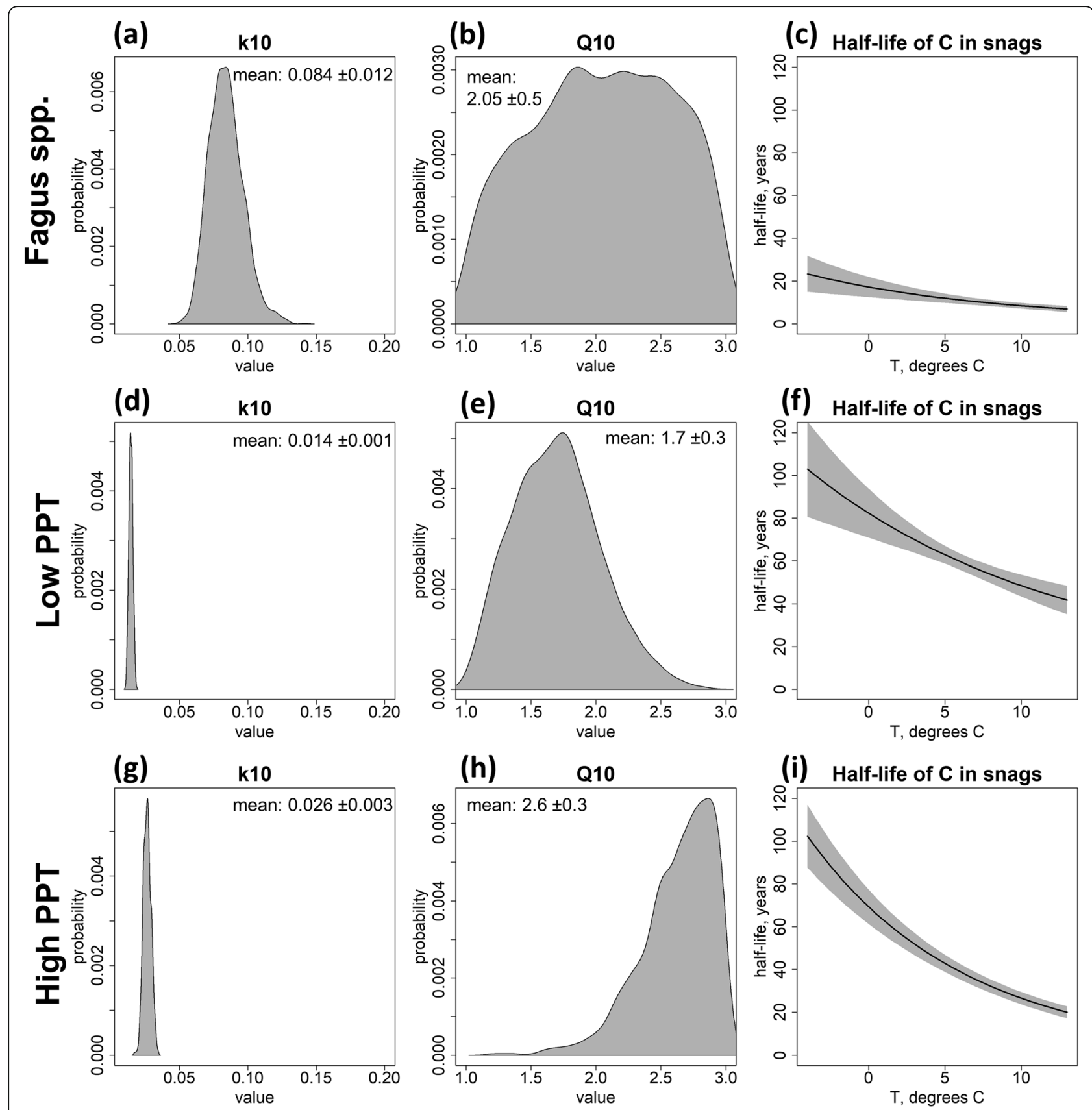

Fig. 3 Posterior parameter distributions for C dynamics in standing snags in plots with F. sylvatica (a, b) low precipitation, i.e. PPT $\leq 1837 \mathrm{~mm}$ (d, e), and high precipitation, i.e. PPT $>1837 \mathrm{~mm}(\mathrm{~g}, \mathrm{~h})$; and the corresponding responses of $\mathrm{C}$ half-lives to temperature $(\mathbf{c}, \mathbf{f}$, $\mathbf{i})$. The range of $x$-axes in the panels with parameter values represents the prior parameter ranges. The half-life of $\mathbf{C}$ in snags in $(\mathbf{c}, \mathbf{f}$, and $\mathbf{i})$ excludes the effect of fall rate

environmental conditions on the dynamics of woodcolonizing microbes in Swiss forest was similar to those in forests in similar climates across Eurasia and North America, and compared our wood decay rates to the rates reported in other studies. Angers et al. (2011) measured snag decay rates of two softwood species in northwestern Quebec, Canada, and reported the range of 0.0058 to $0.0274 \mathrm{yr}^{-1}$, whereas our temperature-adjusted estimates yielded the range of $0.0068-0.011 \mathrm{yr}^{-1}$, thus underestimating variability in the decay rate of softwood snags for the given temperature. Yatskov et al. (2003) estimated decay rates in St. Petersburg region of Russia $\left(\mathrm{MAT}=3.4^{\circ} \mathrm{C}, \mathrm{PPT}=708 \mathrm{~mm}\right)$ for $P$. abies snags to be $0.044 \mathrm{yr}^{-1} \pm 0.018$ (SE), which was the highest decay rate found among the studied conifers; and the estimates for Pinus siberica in Irkutsk region $\left(\mathrm{MAT}=-0.6^{\circ} \mathrm{C}\right.$, PPT $=$ $216 \mathrm{~mm}$ ) and Pinus koraiensis in Khabarovsk region $\left(\mathrm{MAT}=-1.9^{\circ} \mathrm{C}, \mathrm{PPT}=909 \mathrm{~mm}\right)$ to be $0.003 \pm(0.001)$ 


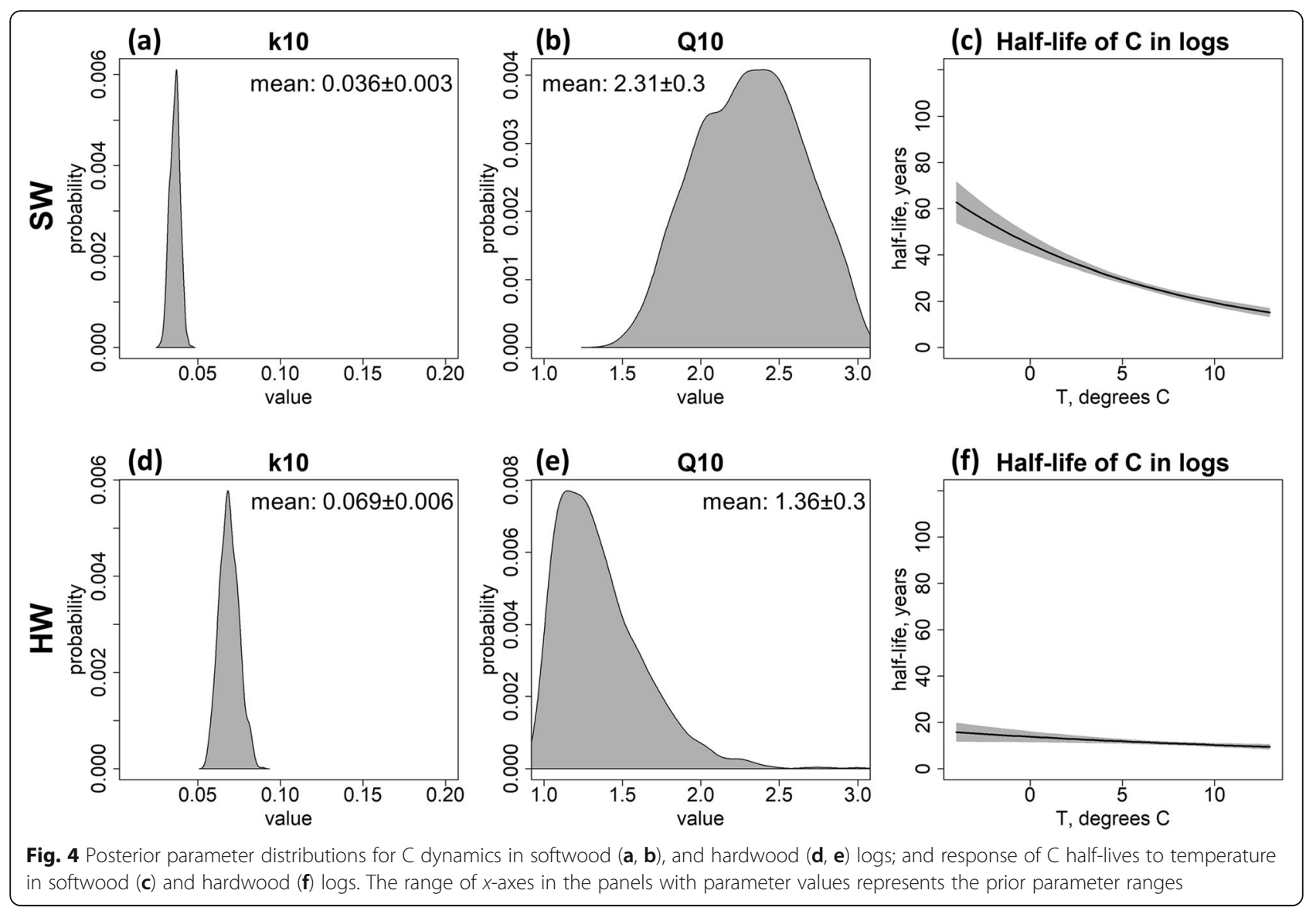

$\mathrm{yr}^{-1}$ and $0.003 \pm(0.002) \mathrm{yr}^{-1}$, respectively. Our decay rate estimates for $P$. abies snags for the corresponding climate conditions were lower, ranging from 0.008 to $0.013 \mathrm{yr}^{-1}$, however the turnover rates for the colder sites were higher than reported in (Yatskov et al. 2003), ranging from 0.006 to $0.011 \mathrm{yr}^{-1}$ for both Pinus siberica and Pinus koraiensis sites.

Aakala (2010) analysed decay of Picea abies snags at three locations in Finland and northwestern Russia and reported the half-lives between 12 and 27 years, whereas our estimates for the corresponding species group, once adjusted for local mean annual temperatures, and the median fall rate estimated in this study ranged between 14 and 15 years. A study in eastern Europe reported that the residence time of $P$. abies snags was over 40 years (Vacek et al. 2015), which was close to our estimates (45-48 years) after adjustment for site temperature and precipitation $\left(\mathrm{MAT}=4.5^{\circ} \mathrm{C}, \quad \mathrm{PPT}=713 \mathrm{~mm}\right.$, obtained from WorldClim database, Fick and Hijmans 2017) and the median fall rate of $0.04 \mathrm{yr}^{-1}$ estimated in this study.

Unlike the estimates for snag decay dynamics, our estimates for softwood log decay often encompassed the ranges reported in the literature, however there were cases where observed log decay rates were faster than the ones calculated with the parameters calibrated in this study. The baseline log decay rate for both hardwoods and softwoods obtained in this study was 0.04 $\mathrm{yr}^{-1}$ (Fig. 1d) and was lower than the estimate obtained using the data from Canada's NFI in Hararuk et al. (2017), $0.064 \mathrm{yr}^{-1}$, as well as the estimate from global deadwood decay analysis (Harmon et al. 2020), 0.059 $\mathrm{yr}^{-1}$, but was close to the baseline decay rate assumed in Kurz et al. (2009), $0.037 \mathrm{yr}^{-1}$. The maximum likelihood temperature sensitivity of log decay in Swiss forests was substantially higher than the one obtained for logs across Canada (2.6 vs. 1.53, Hararuk et al. 2017), however it was close to the temperature sensitivity estimated from the data on deadwood decay across the globe (2.59, Harmon et al. 2020). At three locations in Finland and Russia half-lives of Picea abies logs had a fairly short range of 20-40 years (Aakala 2010), whereas our estimates calculated for those sites ranged from 38 to 61 years. Parameters calibrated against Swiss NFI also underestimated the decay rates of softwood logs at a site in Russia: the decay rates calculated with our parameters ranged from 0.018 to $0.026 \mathrm{yr}^{-1}$, whereas the observed decay rates were0.033-0.034 $\mathrm{yr}^{-1}$ (Krankina and Harmon 1995). However, repeated measurements in the same region resulted in slower decay rates of conifer logs, ranging from 0.015 to $0.049 \mathrm{yr}^{-1}$ (Yatskov 

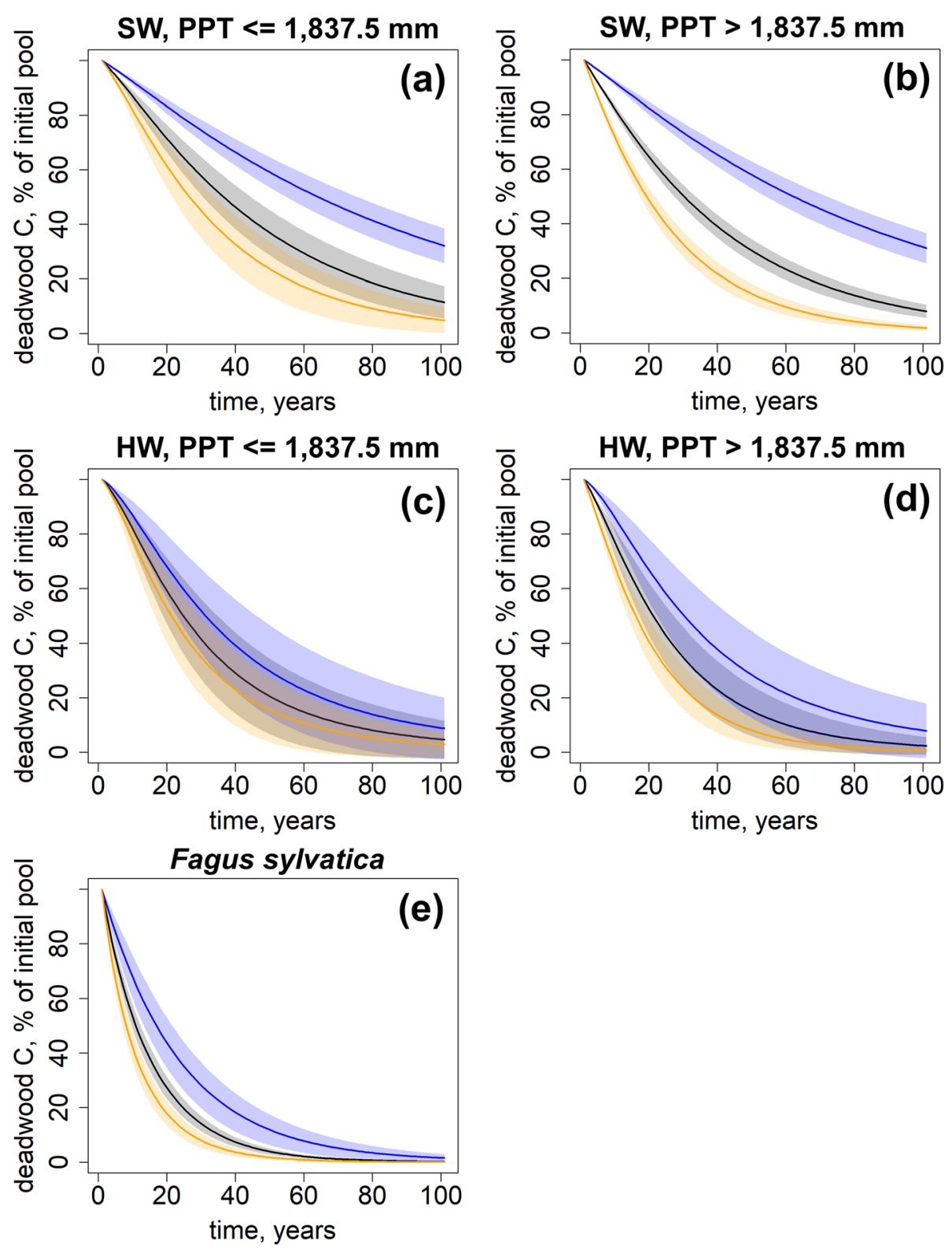

Fig. 5 Total wood decay rate with incorporated snag decay, fall rates, and log decay under mean annual temperatures of $-1.9^{\circ} \mathrm{C}, 7^{\circ} \mathrm{C}$, and $12^{\circ} \mathrm{C}$, representing the coldest, average, and warmest forested sites in Switzerland, respectively. The shaded areas represent \pm 1 SD from the mean values and the variability originates from the uncertainty in parameters (Figs. 3 and 4) as well as uncertainty in the fall rates (Supp. Figure S1)

et al. 2003), which was more consistent with our findings. Petrillo et al. (2016) reported that Picea abies decay rates ranged from 0.01 to $0.025 \mathrm{yr}^{-1}$ for the sites with MAT ranging from 0 to $8.2^{\circ} \mathrm{C}$, and softwood decay rates for these sites calculated with the calibrated parameters obtained in this study ranged from 0.0126 to $0.034 \mathrm{yr}^{-1}$. In the Western Carpathians, residence times of $A$. alba and $P$. abies logs ranged between 44 and 119 (Přívětivý et al. 2018) and were close to our estimates for the softwood logs decomposing under the same climatic conditions ( $74-115$ years). Decay rates for softwood logs at a site in southwest Germany calculated with the parameters estimated in this study $\left(0.024-0.03 \mathrm{yr}^{-1}\right)$ were close to the range estimated by authors for $P$. abies logs, which was $0.023 \pm 0.007 \mathrm{yr}^{-1}$ (Herrmann and Bauhus 2013); and similarly, at the site in Czech Republic our calibrated parameters produced the residence times of softwood logs that were fairly close to the observed residence times of $P$. abies (7895 years vs. $50-85$ years, Vacek et al. 2015). Our range for softwood log decay rates at the sites in southern Germany and south-east France $\left(0.025-0.042 \mathrm{yr}^{-1}\right)$ 
agreed well with the estimates reported by Herrmann et al. (2015), which ranged from 0.021 to $0.05 \mathrm{yr}^{-1}$. Lastly, the range of the decay rates calculated with our parameters for softwood logs across the eastern USA tended to be wider, i.e. more sensitive to temperature (0.014- $0.077 \mathrm{yr}^{-1}$ for temperature range of $\left.1.4-19.8^{\circ} \mathrm{C}\right)$ compared to the observed values, which spanned from 0.024 to $0.04 \mathrm{yr}^{-1}$ for the same temperature range (Russell et al. 2014).

The parameters for hardwood logs produced turnover rates and residence times that were close to the observed values at the sites outside Swiss forests. Fagus sylvatica logs were reported to decompose within 20 to 40 years at some sites in Czech Republic (Vacek et al. 2015), which agrees with our estimates of 31-52 years for that climate; at a site in southwest Germany the decay rates of $F$. sylvatica logs were reported to be $0.052 \pm 0.19 \mathrm{yr}^{-1}$ (Herrmann and Bauhus 2013), which was also close to our estimates of 0.05$0.074 \mathrm{yr}^{-1}$ for the climate at that location. Our range for hardwood log decay rates at the sites in southern Germany and south-east France (0.054-0.075 $\mathrm{yr}^{-1}$ ) agreed well with the estimates reported by Herrmann et al. (2015), which ranged from 0.035 to $0.078 \mathrm{yr}^{-1}$. Lastly, the range and temperature sensitivities of hardwood log decay rates across the eastern USA were 0.041-0.0794 $\mathrm{yr}^{-1}$ for temperature range 1.4$19.8^{\circ} \mathrm{C}$, and were close to the observed range of 0.043-0.064 $\mathrm{yr}^{-1}$ (Russell et al. 2014).

\section{Effects of environment, plant traits, and disturbance on wood decay}

Temperature, precipitation and plant traits affected snag decay at Swiss NFI plots. Decay of $F$. sylvatica snags was significantly faster compared to the decay of snags belonging to other species even within hardwoods, and this difference was not explained by site-specific climatic variables (Figs. 2 and 3). The reasons behind such distinction in $F$. sylvatica decay are not straightforward, because the chemical composition of beech wood is similar to that of other hardwood species (Pettersen 1984; Popescu et al. 2011), however some evidence that fungal decay of beech wood occurred at lower moisture contents compared to other species (Meyer and Brischke 2015) may point at lower inherent resistance of beech wood to fungal decay. Indeed, results from Maringer et al. (2016) who showed that fungi infestations are an important driver of $F$. sylvatica mortality. It is important to account for this distinction in beech wood decay and investigate it further, given the spatial distribution of $F$. sylvatica across Europe (Huntley et al. 1989). Lastly, understanding of patterns of wood decay could be further improved by using species-specific wood densities at each decay class instead of using $F$. sylvatica densities for hardwoods and P. abies densities for softwoods, which could have introduced a bias to our results.

For snags we found a precipitation threshold of 1837 $\mathrm{mm}$, which resulted in the highest contrast in decomposition speed of all species, except F. sylvatica. This threshold is fairly high compared to average precipitation across Swiss forests $(1453 \pm 14 \mathrm{~mm})$, and was higher than the mean annual precipitation range of $1100-1300$ $\mathrm{mm}$ identified by Zell et al. (2009) as optimal for decay, which implies that decomposition should have slowed down at sites where the annual precipitation is above this threshold. However, the data used by Zell et al. (2009) include primarily downed dead wood with smaller DBH compared to those in our study. In our study, snags at high precipitation sites decomposed faster and were more sensitive to temperature compared to the snags in the low precipitation sites (Figs. $3 \mathrm{~d}$, e, g, h). Wood is thought to be decayed mainly by fungi (Cornwell et al. 2009), which grow better in moister conditions (Griffin 1977), therefore higher precipitation likely resulted in higher wood moisture content, facilitating faster fungal decay of snags at Swiss NFI plots. Increased temperature also stimulates microbial metabolism, however this effect weakens under sub-optimal moisture conditions (Suseela et al. 2012), which was detected in Swiss NFI plots as well and manifested as lower Q10 values at drier sites (Fig. 3e, h).

Decay of downed logs was not affected by precipitation (Fig. 2b), which was consistent with findings by Petrillo et al. (2016) and may be due to more stable moisture conditions closer to the soil surface. However, this observation did not agree with a wood decay study at the West Carpathians, where precipitation affected the decay of downed logs, but not standing snags (Přivětivý et al. 2018). Hardwood species decomposed faster and were less sensitive to temperature compared to softwood species. Several substantial differences may have contributed to faster decomposition of hardwoods, such as larger and more continuous vessels, which promotes faster colonization by fungi (Harmon et al. 1986; Wilcox 1973), higher nitrogen content (and lower C:N ratios), which has been shown to stimulate wood decomposition rate (Weedon et al. 2009; Hu et al. 2018), and lower lignin content (Savidge 2000; Weedon et al. 2009; Freschet et al. 2012). Lower temperature sensitivity of hardwood logs decay may have been due to higher substrate quality (i.e. lower wood lignin content and C:N ratios) - a phenomenon that was previously reported for soil organic matter mineralization (Leifeld and Fuhrer 2005).

Although plant traits and temperature were significant predictors for decay rates of standing snags and logs, and precipitation significantly affected decay of standing snags, there was still substantial variability in model residuals that could not be reduced by available predictors 
(Fig. 2). This unexplained variability likely arises from the unaccounted effects of the environment and the resulting biotic dynamics. For instance, the annual precipitation from MeteoSwiss included rain and snow, and while the former could affect the decay through improving the growing conditions for microorganisms, the latter could supply moisture during snowmelt, and, in addition, exert stress on the standing snags, potentially increasing snag fall rates and therefore overall rates of wood decay. In high elevation forests, the aspect of a slope could be another variable that can affect wood decay as shown in (Bardelli et al. 2018) who monitored decomposition of $P$. abies wood blocks in north- and south-facing slopes of the Italian Alps, and found that wood mass loss was $32 \%$ higher in the north- than south-facing slopes. The authors also concluded that higher wood mass loss was due to higher fungal abundance in the cooler and moister north-facing slopes. Snag fall rates could be affected by agent of mortality, site history and management. Snags that originate from fire tend to have lower longevity (Morrison and Raphael 1993), while snags that originate from suppression or insect outbreak (e.g. spruce budworm) tend to have higher longevity (Garber et al. 2005); stands with higher tree density and shorter harvest intervals have reduced snag longevity (Garber et al. 2005; Russell and Weiskittel 2012). Snag longevity is also associated with the exposure to wind (Montoro Girona et al. 2019) as well as the average wind speed (Hogg and Michaelian 2015) and is itself a function of snag decay as it is correlated with presence of fungi and borers on snags (Hogg and Michaelian 2015). Lastly, the unexplained variability in model errors can also arise from microsite conditions and various factors affecting microbial colonization rates, such as proximity of old woody debris, soil animals and other factors discussed in (Bradford et al. 2014), and highlights the importance of further research into controls of wood decomposition processes.

The susceptibility of forests to natural disturbances and the resulting recruitment of dead wood is to some degree a function of forest management (e.g. Seidl et al. 2011). In addition, the amount of dead wood in forests can also be controlled by forest management (e.g. Ranius et al. 2003; Vanderwel et al. 2006a). As the amount and diversity of dead wood is of significance for a variety of forest functions and services such as maintaining biodiversity (e.g. Lassauce et al. 2011) and carbon sequestration (e.g. Russell et al. 2015), our findings on rates of dead wood loss and their environmental controls present valuable information that can be used within carbon budget modelling framework to (1) develop forest management strategies to meet targets of dead wood in forests (cf. Vítková et al. 2018) and (2) improve performance of the carbon budget models, such as the
Carbon Budget Model of the Canadian Forest Sector (Kurz et al. 2009) in Swiss forests.

\section{Conclusions}

In this study we illustrated how long-term dead wood observations collected and remeasured during several NFI campaigns can be used to (1) estimate dead wood decay rates, which are important parameters in process-based $C$ cycle models used to estimate $C$ pools and fluxes, and (2) gain understanding about controls of dead wood dynamics by analyzing the residuals of the model calibrated with the NFI data. We learned that tree characteristics as well as climatic variables have a significant effect on dead wood dynamics, with $F$. sylvatica dead wood decaying the fastest and being least sensitive to climatic conditions compared to other species, and softwoods decaying the slowest and being most sensitive to temperature. It is important to note that the wood decay parameters estimated in this study are not sufficient for predicting the actual $\mathrm{CO}_{2}$ emissions from dead wood, as some unknown fraction of the woody mass will be converted to soil organic matter, where it will continue to decay at a slower rate. However, these parameters can be used for "worst case scenario" estimates of $\mathrm{CO}_{2}$ emissions from heterotrophic respiration associated with dead wood under current conditions or under various climate change and disturbance scenarios. Lastly, the parameters determining wood residence time obtained in this study can be implemented in models used to facilitate sustainable deadwood management strategies in European forests.

\section{Supplementary information}

Supplementary information accompanies this paper at https://doi.org/10. 1186/s40663-020-00248-x.

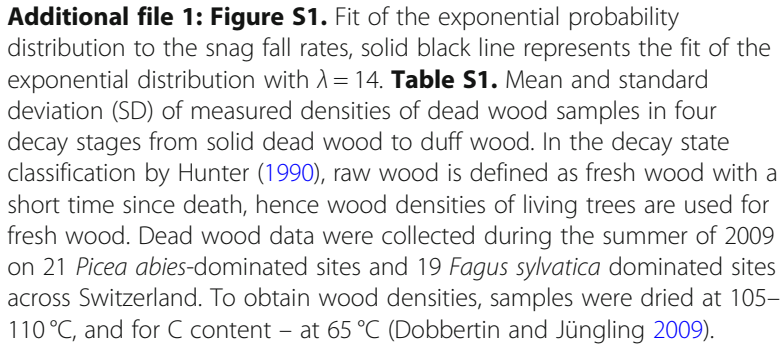

\section{Abbreviations}

C: Carbon; DBH: Diameter at breast height; GHG: Greenhouse gas; MAT: Mean annual temperature; MCMC: Markov Chain Monte Carlo; NFI: National Forest Inventory; PPT: Annual precipitation; Spp.: Species; UNFCCC: United Nations Framework Convention on Climate Change

\section{Acknowledgements}

We thank the Swiss NFI team for data collection, processing and analysis, and three anonymous reviewers who helped improve this manuscript. 


\section{Authors' contributions}

$\mathrm{OH}$ conceived the study and performed the analyses; all authors interpreted the results and contributed to writing. All authors read and approved the final manuscript.

\section{Funding}

M. Didion received financial support from the Swiss Federal Office for the Environment; O. Hararuk and W.A. Kurz received financial support from the Canadian Forest Service, Natural Resources Canada.

\section{Availability of data and materials}

The datasets used and/or analysed during the current study are available from Dr. Markus Didion (markus.didion@wsl.ch) on reasonable request.

\section{Ethics approval and consent to participate}

Not applicable.

\section{Consent for publication}

Not applicable.

\section{Competing interests}

The authors declare that they have no competing interests.

\section{Author details}

'Department of Biology, University of Central Florida, 4110 Libra Dr, Orlando, FL 32816, USA. ${ }^{2}$ Pacific Forestry Centre, 506 Burnside Road West, Victoria, British Columbia V8Z 1M5, Canada. ${ }^{3}$ Swiss Federal Research Institute WSL, Zürcherstrasse 111, 8903 Birmensdorf, Switzerland.

\section{Received: 27 November 2019 Accepted: 22 May 2020}

\section{Published online: 09 June 2020}

\section{References}

Aakala T (2010) Coarse woody debris in late-successional Picea abies forests in northern Europe: variability in quantities and models of decay class dynamics. Forest Ecol Manag 260(5):770-779

Angers VA, Drapeau P, Bergeron Y (2010) Snag degradation pathways of four north American boreal tree species. Forest Ecol Manag 259(3):246-256

Angers VA, Drapeau P, Bergeron Y (2011) Mineralization rates and factors influencing snag decay in four north American boreal tree species. Can J For Res 42(1):157-166

Bardelli T, Ascher-Jenull J, Burkia Stocker E, Fornasier F, Arfaioli P, Fravolini G, Alves Medeiros LR, Egli M, Pietramellara G, Insam H, Gómez-Brandón M (2018) Impact of slope exposure on chemical and microbiological properties of Norway spruce deadwood and underlying soil during early stages of decomposition in the Italian Alps. CATENA 167:100-115

Besag J, Green P, Higdon D, Mengersen K (1995) Bayesian computation and stochastic systems. Stat Sci 10(1):3-41

Boddy L (2001) Fungal community ecology and wood decomposition processes in angiosperms: from standing tree to complete decay of coarse woody debris. Ecol Bull 49:43-56

Box GEP, Tiao GC (1992) Nature of Bayesian inference. In: Bayesian inference in statistical analysis. Wiley, pp 1-75

Bradford MA, Warren li RJ, Baldrian P, Crowther TW, Maynard DS, Oldfield EE, Wieder WR, Wood SA, King JR (2014) Climate fails to predict wood decomposition at regional scales. Nat Clim Chang 4:625

Brändli U-B (2010) Schweizerisches Landesforstinventar: Ergebnisse der dritten Erhebung: 2004-2006. Swiss Federal Research Institute (WSL), Swiss

Brändli UB, Abegg M, Allgaier Leuch B (2020b) Schweizerisches Landesforstinventar: Ergebnisse der vierten Erhebung 2009-2017. (results of the fourth Swiss National Forest Inventory 2009-2017), vol 312. Swiss Federal Research Institute for Forest, Snow and Landscape Research, Birmensdorf (ZH) and Federal Office for the Environment (FOEN), Bern

Brändli U-B, Abegg M, Düggelin C (2020a) Kapitel 5: Biologische Vielfalt. (chapter 5: biological diversity). In: Brändli UB, Abegg M, Allgaier Leuch B (eds) Schweizerisches Landesforstinventar: Ergebnisse der vierten Erhebung 20092017. (results of the fourth Swiss National Forest Inventory 2009-2017). Swiss Federal Research Institute for Forest, Snow and Landscape Research, Birmensdorf (ZH) and Federal Office for the Environment (FOEN), Bern, pp 189-237
Brändli U-B, Hägeli M (2019) In: Swiss NFI at a Glance (ed) Swiss National Forest Inventory-Methods and models of the fourth assessment. Springer, pp 3-35

Brassel P, Brändli U (1999) In: Schweizerisches Landesforstinventar (ed) Ergebnisse der Zweitaufnahme 1993-1995, Eidgenössische Forschungsanstalt für Wald und Schnee und Landschaft, Bundesamt für Umwelt und Wald und Landschaft. Haupt Verlag, Bern

Churkina G, Running SW (1998) Contrasting climatic controls on the estimated productivity of global terrestrial biomes. Ecosystems 1(2):206-215

Cioldi F, Brändli U-B, Didion M, Fischer C, Ginzler C, Herold A, Huber M, Thürig E (2020) Kapitel 2: Waldressourcen. (chapter 2: forest resources). In: Brändli UB, Abegg M, Allgaier Leuch B (eds) Schweizerisches Landesforstinventar: Ergebnisse der vierten Erhebung 2009-2017. (results of the fourth Swiss National Forest Inventory 2009-2017). Swiss Federal Research Institute for Forest, Snow and Landscape Research, Birmensdorf (ZH) and Federal Office for the Environment (FOEN), Bern, pp 35-119

Cornwell WK, Cornelissen JHC, Allison SD, Bauhus J, Eggleton P, Preston CM, Scarff F, Weedon JT, Wirth C, Zanne AE (2009) Plant traits and wood fates across the globe: rotted, burned, or consumed? Glob Chang Biol 15(10):2431-2449

Delignette-Muller ML, Dutang C (2015) Fitdistrplus: an R package for fitting distributions. J Stat Softw 64(4):34

Didion M, Frey B, Rogiers N, Thürig E (2014) Validating tree litter decomposition in the Yasso07 carbon model. Ecol Model 291:58-68

Didion M, Herold A, Thürig E (2019) Whole tree biomass and carbon stock. In: Fischer C, Traub B (eds) Swiss National Forest Inventory - methods and models of the fourth assessment. Springer International Publishing, Cham, pp $243-248$

Dobbertin M, Jüngling E (2009) Totholzverwitterung und C-Gehalt. Zwischenergebnisse. Swiss Federal Research Institute for Forest, snow and landscape research, Birmensdorf, Swiss

Drake JE, Davis SC, Raetz LM, DeLucia EH (2011) Mechanisms of age-related changes in forest production: the influence of physiological and successional changes. Glob Chang Biol 17(4):1522-1535

EAFV (Eidgenössische Anstalt für das forstliche Versuchswesen), BFL (Bundesamt für Forstwesen und Landschaftsschutz) (1988) Schweizerisches Landesforstinventar: Ergebnisse der Erstaufnahme 1982-1986. Berichte der Eidgenöss. Forsch. Anst. Wald Schnee Landsch. 305. Eidg. Anstalt für das forstliche Versuchswesen, Birmensdorf

Fick SE, Hijmans RJ (2017) WorldClim 2: new 1-km spatial resolution climate surfaces for global land areas. Int I Climatol 37(12):4302-4315

Freschet GT, Weedon JT, Aerts R, van Hal JR, Cornelissen JHC (2012) Interspecific differences in wood decay rates: insights from a new short-term method to study long-term wood decomposition. J Ecol 100(1):161-170

Garber SM, Brown JP, Wilson DS, Maguire DA, Heath LS (2005) Snag longevity under alternative silvicultural regimes in mixed-species forests of Central Maine. Can J For Res 35(4):787-796

Gelman A, Roberts G, Gilks W (1996) Efficient metropolis jumping rules. In: Bernardo JM, Berger JO, Dawid AP, Smith AFM (eds) Bayesian statistics 5. Oxford Science Publications, Clarendon Press, p 832

Goodale CL, Apps MJ, Birdsey RA, Field CB, Heath LS, Houghton RA, Jenkins JC, Kohlmaier GH, Kurz W, Liu S, Nabuurs G-J, Nilsson S, Shvidenko AZ (2002) Forest carbon sinks in the northern hemisphere. Ecol Appl 12(3):891-899

Griffin DM (1977) Water potential and wood-decay fungi. Annu Rev Phytopathol 15(1):319-329

Haario H, Saksman E, Tamminen J (2001) An adaptive metropolis algorithm. Bernoulli 7(2):223-242

Hararuk O, Shaw C, Kurz WA (2017) Constraining the organic matter decay parameters in the CBM-CFS3 using Canadian National Forest Inventory data and a Bayesian inversion technique. Ecol Model 364:1-12

Harmon ME, Fasth BG, Yatskov M, Kastendick D, Rock J, Woodall CW (2020) Release of coarse woody detritus-related carbon: a synthesis across forest biomes. Carbon Balance Manag 15(1):1

Harmon ME, Franklin JF, Swanson FJ, Sollins P, Gregory SV, Lattin JD, Anderson NH, Cline SP, Aumen NG, Sedell JR, Lienkaemper GW, Cromack K, Cummins KW (1986) Ecology of coarse woody debris in temperate ecosystems. In: MacFadyen A \& Ford ED (eds) Advances in ecological research. Academic Press. 133-302

Hérault B, Beauchêne J, Muller F, Wagner F, Baraloto C, Blanc L, Martin J-M (2010) Modeling decay rates of dead wood in a neotropical forest. Oecologia 164(1):243-251

Herrmann S, Bauhus J (2013) Effects of moisture, temperature and decomposition stage on respirational carbon loss from coarse woody debris (CWD) of important European tree species. Scand J Forest Res 28(4):346-357 
Herrmann S, Kahl T, Bauhus J (2015) Decomposition dynamics of coarse woody debris of three important central European tree species. Forest Ecosyst 2(1): 27. https://doi.org/10.1186/s40663-015-0052-5

Hilger AB, Shaw CH, Metsaranta JM, Kurz WA (2012) Estimation of snag carbon transfer rates by ecozone and lead species for forests in Canada. Ecol Appl 22(8):2078-2090

Hogg EH, Michaelian M (2015) Factors affecting fall down rates of dead aspen (Populus tremuloides) biomass following severe drought in west-Central Canada. Glob Chang Biol 21(5):1968-1979

Hothorn T, Hornik K, Zeileis A (2006) Unbiased recursive partitioning: a conditional inference framework. J Comput Graph Stat 15(3):651-674

Hothorn T, Hornik K, Zeileis A (2015) Ctree: conditional inference trees. The comprehensive $\mathrm{R}$ archive network, pp 1-34

Hu Z, Michaletz ST, Johnson DJ, McDowell NG, Huang Z, Zhou X, Xu C (2018) Traits drive global wood decomposition rates more than climate. Glob Chang Biol 24(11):5259-5269

Hunter ML (1990) Wildlife, forests, and forestry. Principles of managing forests for biological diversity. Prentice Hall, Englewood Cliffs

Huntley B, Bartlein PJ, Prentice IC (1989) Climatic control of the distribution and abundance of beech (Fagus L.) in Europe and North America. J Biogeogr 16(6):551-560

Kahl T, Mund M, Bauhus J, Schulze E-D (2012) Dissolved organic carbon from European beech logs: patterns of input to and retention by surface soil. Écoscience 19(4):364-373

Keenan TF, Davidson E, Moffat AM, Munger W, Richardson AD (2012) Using model-data fusion to interpret past trends, and quantify uncertainties in future projections, of terrestrial ecosystem carbon cycling. Glob Chang Biol 18(8):2555-2569

Krankina ON, Harmon ME (1995) Dynamics of the dead wood carbon pool in northwestern Russian boreal forests. Water Air Soil Pollut 82(1):227-238

Kurz WA, Dymond CC, White TM, Stinson G, Shaw CH, Rampley GJ, Smyth C, Simpson BN, Neilson ET, Trofymow JA, Metsaranta J, Apps MJ (2009) CBMCFS3: a model of carbon-dynamics in forestry and land-use change implementing IPCC standards. Ecol Model 220(4):480-504

Lanz A, Fischer C, Abegg M (2019) Sampling design and estimation procedures. In: Fischer C, Traub B (eds) Swiss National Forest Inventory - methods and models of the fourth assessment. Springer International Publishing, Cham, pp 39-92

Lassauce A, Paillet Y, Jactel H, Bouget C (2011) Deadwood as a surrogate for forest biodiversity: meta-analysis of correlations between deadwood volume and species richness of saproxylic organisms. Ecol Indic 11(5):1027-1039

Leifeld J, Fuhrer J (2005) The temperature response of $\mathrm{CO}_{2}$ production from bulk soils and soil fractions is related to soil organic matter quality. Biogeochemistry 75(3):433-453

Luo Y, Keenan TF, Smith M (2015) Predictability of the terrestrial carbon cycle. Glob Chang Biol 21(5):1737-1751

Mackensen J, Bauhus J, Webber E (2003) Decomposition rates of coarse woody debris - a review with particular emphasis on Australian tree species. Aust J Bot 51(1):27-37

Mäkinen H, Hynynen J, Siitonen J, Sievänen R (2006) Predicting the decomposituin of scots pine, Norway spruce, and birch stems in Finland. Ecol Appl 16(5):1865-1879

Maringer J, Ascoli D, Küffer N, Schmidtlein S, Conedera M (2016) What drives European beech (Fagus sylvatica L.) mortality after forest fires of varying severity? Forest Ecol Manag 368:81-93

MeteoSwiss, Federal Office of Meteorology and Climatology (2016a) Monthly and yearly mean temperature: TabsM and TabsY. MeteoSwiss FOoMaC, Zurich

MeteoSwiss, Federal Office of Meteorology and Climatology (2016b) Monthly and yearly precipitation: RhiresM and RhiresY. MeteoSwiss FOoMaC, Zurich

MeteoSwiss, Federal Office of Meteorology and Climatology (2019) Spatial climate analyses https://www.meteoswiss.admin.ch/home/climate/swissclimate-in-detail/raeumliche-klimaanalysen.html. Accessed January 29, 2020

Meyer L, Brischke C (2015) Fungal decay at different moisture levels of selected European-grown wood species. Int Biodeterior Biodegrad 103:23-29

Montoro Girona M, Morin H, Lussier J-M, Ruel J-C (2019) Post-cutting mortality following experimental silvicultural treatments in unmanaged boreal forest stands. Front Forest Glob Change 2:4

Morrison ML, Raphael MG (1993) Modeling the dynamics of snags. Ecol Appl 3(2): 322-330

Mosegaard K, Sambridge M (2002) Monte Carlo analysis of inverse problems. Inverse Prob 18(3):R29-R54
Oberle B, Ogle K, Zanne AE, Woodall CW (2018) When a tree falls: controls on wood decay predict standing dead tree fall and new risks in changing forests. PLoS One 13(5):e0196712

Olajuyigbe S, Tobin B, Nieuwenhuis M (2012) Temperature and moisture effects on respiration rate of decomposing logs in a Sitka spruce plantation in Ireland. Forestry 85(4):485-496

Paletto A, Tosi V (2010) Deadwood density variation with decay class in seven tree species of the Italian Alps. Scand J Forest Res 25(2):164-173

Pan Y, Birdsey R, Hom J, McCullough K, Clark K (2006) Improved estimates of net primary productivity from MODIS satellite data at regional and local scales. Ecol Appl 16(1):125-132

Parton WJ, Hanson PJ, Swanston C, Torn M, Trumbore SE, Riley W, Kelly R (2010) ForCent model development and testing using the enriched background isotope study experiment. J Geophys Res Biogeosci 115(G4):G04001

Petrillo M, Cherubini P, Fravolini G, Marchetti M, Ascher-Jenull J, Schärer M, Synal HA, Bertoldi D, Camin F, Larcher R, Egli M (2016) Time since death and decay rate constants of Norway spruce and European larch deadwood in subalpine forests determined using dendrochronology and radiocarbon dating. Biogeosciences 13(5):1537-1552

Pettersen RC (1984) The chemical composition of wood. Chem Solid Wood 207: $57-126$

Popescu M-C, Popescu C-M, Lisa G, Sakata Y (2011) Evaluation of morphological and chemical aspects of different wood species by spectroscopy and thermal methods. J Mol Struct 988(1):65-72

Pregitzer KS, Euskirchen ES (2004) Carbon cycling and storage in world forests: biome patterns related to forest age. Glob Chang Biol 10(12):2052-2077

Prescott CE (2010) Litter decomposition: what controls it and how can we alter it to sequester more carbon in forest soils? Biogeochemistry 101(1):133-149

Přivětivý T, Adam D, Vrška T (2018) Decay dynamics of Abies alba and Picea abies deadwood in relation to environmental conditions. Forest Ecol Manag 427:250-259

Ranius T, Kindvall O, Kruys N, Jonsson BG (2003) Modelling dead wood in Norway spruce stands subject to different management regimes. Forest Ecol Manag 182(1):13-29

Russell MB, Fraver S, Aakala T, Gove JH, Woodall CW, D'Amato AW, Ducey M (2015) Quantifying carbon stores and decomposition in dead wood: a review. Forest Ecol Manag 350:107-128

Russell MB, Weiskittel AR (2012) Assessing and modeling snag survival and decay dynamics for the primary species in the Acadian forest of Maine, USA. Forest Ecol Manag 284:230-240

Russell MB, Woodall CW, Fraver S, D'Amato AW, Domke GM, Skog KE (2014) Residence times and decay rates of downed woody debris biomass/carbon in eastern US forests. Ecosystems 17(5):765-777

Saatchi SS, Harris NL, Brown S, Lefsky M, Mitchard ETA, Salas W, Zutta BR, Buermann W, Lewis SL, Hagen S, Petrova S, White L, Silman M, Morel A (2011) Benchmark map of forest carbon stocks in tropical regions across three continents. PNAS 108(24):9899

Savidge R (2000) Biochemistry of seasonal cambial growth and wood formationan overview of the challenges. In: Savidge RA, Barnett JR, Napier R (eds) Cell and molecular biology of wood formation. BIOS Scientific Publishers Ltd. Oxford, UK, pp 1-30

Scheffer TC (1966) Natural resistance of wood to microbial deterioration. Annu Rev Phytopathol 4(1):147-168

Scheller RM, Mladenoff DJ (2004) A forest growth and biomass module for a landscape simulation model, LANDIS: design, validation, and application. Ecol Model 180(1):211229

Seidl R, Fernandes PM, Fonseca TF, Gillet F, Jönsson AM, Merganičová K, Netherer S, Arpaci A, Bontemps J-D, Bugmann H, González-Olabarria JR, Lasch P, Meredieu C, Moreira F, Schelhaas M-J, Mohren F (2011) Modelling natural disturbances in forest ecosystems: a review. Ecol Model 222(4):903-924

Shaw CH, Hilger AB, Metsaranta J, Kurz WA, Russo G, Eichel F, Stinson G, Smyth C, Filiatrault M (2014) Evaluation of simulated estimates of forest ecosystem carbon stocks using ground plot data from Canada's National Forest Inventory. Ecol Model 272:323-347

Shorohova E, Kapitsa E (2014) Influence of the substrate and ecosystem attributes on the decomposition rates of coarse woody debris in European boreal forests. Forest Ecol Manag 315:173-184

Spall JC (2005) Introduction to stochastic search and optimization: estimation, simulation, and control. Wiley. https://doi.org/10.1002/0471722138

Storaunet KO, Rolstad J (2002) Time since death and fall of Norway spruce logs in old-growth and selectively cut boreal forest. Can J For Res 32(10):18011812 
Storaunet KO, Rolstad J (2004) How long do Norway spruce snags stand? Evaluating four estimation methods. Can J For Res 34(2):376-383

Suseela V, Conant RT, Wallenstein MD, Dukes JS (2012) Effects of soil moisture on the temperature sensitivity of heterotrophic respiration vary seasonally in an old-field climate change experiment. Glob Chang Biol 18(1):336-348

Tomppo E, Gschwantner T, Lawrence M, McRoberts RE, Gabler K, Schadauer K, Vidal C, Lanz A, Ståhl G, Cienciala E (2010) In: National forest inventories (ed) Pathways for common reporting. Springer, New York

Vacek S, Vacek Z, Bílek L, Hejcmanová P, Sticha V, Remes J (2015) The dynamics and structure of dead wood in natural spruce-beech forest stand-a 40 year case study in the Krkonose National Park. Dendrobiology 73:21-32

Vanderwel MC, Caspersen JP, Woods ME (2006a) Snag dynamics in partially harvested and unmanaged northern hardwood forests. Can J For Res 36(11): 2769-2779

Vanderwel MC, Malcolm JR, Smith SM (2006b) An integrated model for snag and downed woody debris decay class transitions. Forest Ecol Manag 234(1):4859

Vítková L, Bače R, Kjučukov P, Svoboda M (2018) Deadwood management in central European forests: key considerations for practical implementation. Forest Ecol Manag 429:394-405

Wang YP, Law RM, Pak B (2010) A global model of carbon, nitrogen and phosphorus cycles for the terrestrial biosphere. Biogeosciences 7(7):22612282

Weedon JT, Cornwell WK, Cornelissen JHC, Zanne AE, Wirth C, Coomes DA (2009) Global meta-analysis of wood decomposition rates: a role for trait variation among tree species? Ecol Lett 12(1):45-56

Wilcox WW (1973) Degradation in relation to wood structure. In: Nicholas DD (ed) Wood deterioration and its prevention by preservative treatments. Syracuse University Press 1:107-148

Williams M, Schwarz PA, Law BE, Irvine J, Kurpius MR (2005) An improved analysis of forest carbon dynamics using data assimilation. Glob Chang Biol 11(1):89-105

Xu T, White L, Hui D, Luo Y (2006) Probabilistic inversion of a terrestrial ecosystem model: analysis of uncertainty in parameter estimation and model prediction. Global Biogeochem Cycl 20(2):GB2007

Yatskov M, Harmon ME, Krankina ON (2003) A chronosequence of wood decomposition in the boreal forests of Russia. Can J For Res 33(7):1211-1226

Zell J, Kändler G, Hanewinkel M (2009) Predicting constant decay rates of coarse wood debris - a meta-analysis approach with a mixed model. Ecol Model 220(7):904-912

\section{Submit your manuscript to a SpringerOpen ${ }^{\circ}$ journal and benefit from:}

- Convenient online submission

- Rigorous peer review

- Open access: articles freely available online

- High visibility within the field

- Retaining the copyright to your article

Submit your next manuscript at $\boldsymbol{\nabla}$ springeropen.com 